\title{
Systems serology: profiling vaccine induced humoral immunity against HIV
}

\author{
Amy W. Chung ${ }^{1 *} \mathbb{D}$ and Galit Alter ${ }^{2 *}$
}

\begin{abstract}
The results of the RV144 HIV vaccine, in combination with several recent non-human primate vaccine studies continue to highlight the potentially protective role of non-neutralizing Fc functional antibodies in HIV vaccine design. For many currently licensed vaccines, assays that detect antigen-specific antibody titers or neutralization levels have been used as a correlate of protection. However, antibodies can confer protection through multiple other mechanisms beyond neutralization, or mechanisms which are not dependent on total antibody titers. Alternative strategies that allow us to further understand the precise mechanisms by which antibodies confer protection against HIV and other infectious pathogens is vitally important for the development of future vaccines. Systems serology aims to comprehensively survey a diverse array of antibody features and functions, in order to simultaneously examine the mechanisms behind and distinguish the most important antibody features required for protection, thus identifying key targets for future experimental vaccine testing. This review will focus on the technical aspects required for the application of Systems serology and summarizes the recent advances provided by application of this systemic analytical approach.
\end{abstract}

Keywords: Antibody, Systems serology, ADCC, IgG, Subclass, HIV, Vaccine, Fc effector function

\section{Introduction: Vaccine-induced humoral immunity} Vaccines are one of the world's most powerful public health interventions. Many of the currently licensed human vaccines are believed to confer protection through the induction of antigen-specific antibodies [1]. These include vaccines against a range of viral pathogens such as hepatitis [2], human papilloma virus [3], polio [4], influenza [5] and yellow fever [6], and the bacterial pathogens including pneumococcus [7] and pertussis [8].

The standard method of assessing vaccine-induced protective humoral immunity is through assays that detect either the level of antigen-specific antibody titres post vaccination, (typically via enzyme linked immunosorbent assays (ELISAs)), the quantity of 'functional' antibody responses through inhibition of the pathogen or toxin (e.g. neutralization for polio virus, hemagglutination

\footnotetext{
*Correspondence: awchung@unimelb.edu.au; galter@mgh.harvard.edu ${ }^{1}$ Department of Microbiology and Immunology, Peter Doherty Institute for Infection and Immunity, University of Melbourne, 792 Elizabeth St., Melbourne, VIC 3000, Australia

2 Ragon Institute of MGH, MIT and Harvard University, 400 Technology Square, Cambridge, MA 02139, USA
}

assay (HAI) for influenza) or opsonophagocytic activity (e.g. pneumococcal bacteria) [1,9]. These conventional immunological methods are extremely valuable, as they are high throughput, easily standardizable, and thus will remain essential for evaluating vaccine responses. However, the caveat to many of these assays is that they measure a single or very limited number of humoral characteristics, and it is likely that other antibody-mediated mechanisms also contribute to protection against infection in vivo. For many infectious diseases, protection from or infection control is often observable in the absence of antibody neutralization. Instead, accumulating evidence across a spectrum of vaccines has suggested a critical role for additional, non-neutralizing, antibody functions, that is the ability of an antibody to interact with other immune components and effector cells via their Fc portions to mediate killing or control of the pathogen. These mechanism include, but are not limited to, antibody dependent cellular cytotoxicity (ADCC), antibody dependent cellular phagocytosis (ADCP), antibody dependent complement deposition in both protection from and control of HIV [10-13], influenza [14, 15], HSV 
[16, 17], Ebola virus [18], and malaria [19-21]. Thus, alternative strategies that allow us to further understand and assess the precise mechanisms by which antibodies confer protection against pathogens is vitally important for the development and testing of future vaccines.

\section{HIV vaccines}

Three decades after the discovery of HIV, the journey towards the development of a protective HIV vaccine is still ongoing. While the overarching goal of an HIV antibody-based vaccine is to induce broadly neutralizing antibodies, this historically has not proven to be an easy feat [22]. To date, there have only been four different HIV vaccine concepts that have been tested in a total of six human efficacy trials [23]. Of these, the RV144 'Thai' Phase III trial was the first, and only, human HIV vaccine trial to demonstrate moderate efficacy (31.2\%) [24]. Surprisingly, this vaccine did not induce broadly neutralizing antibody responses. Instead non-neutralizing antibodies that recognize a specific region of the HIV Envelope (ENV) variable region 1 and 2 (V1V2) were associated with reduced risk of infection $[25,26]$. Additional follow up analysis of the RV144 trial revealed that ADCC, antibody avidity to ENV and low tier neutralizing antibodies in the absence of IgA were secondary correlates of reduced risk of infection [25].

Based on these discoveries, a major focus of the HIV antibody vaccine field has been dedicated to understanding the functional role of these HIV-binding non-neutralizing antibodies [27]. This has resulted in significant advancements in the technologies available to interrogate non-neutralizing functional antibody responses [28]. It has also emphasized that assessing vaccine-induced humoral immune responses by quantifying the level of antigen-specific antibody titres alone is not a sufficient predictor of antibody protection or even Fc-effector functional capacity. Indeed, studies comparing the moderately protective RV144 vaccine trial [24], consisting of ALVAC-HIV (vCP1521) prime and AIDSVAX B/E protein boosts, with its non-efficacious predecessor, VAX003 vaccine [29], consisting of AIDSVAX B/E protein, revealed that VAX003 resulted in significantly higher total HIV-specific IgG levels compared to RV144 [30, 31]. However, the elevated levels of HIV-specific IgG induced by VAX003 were of a less functional nature, with elevated levels of poorly functional IgG4 subclass antibodies, that competed for antigen occupancy, thereby blocking Fc effector functions [31]. In comparison, RV144 vaccination induced lower total HIV-specific IgG titers, but resulted in enhanced levels of highly functional IgG3 subclass antibodies that had the capacity to induce polyfunctional non-neutralizing responses including ADCC, $\mathrm{ADCP}$ and antibody-mediated activation of NK cells
[31]. These studies highlight the complexity of antibody interactions in vivo and suggest that broader Fc effector profiling and analytical methods may be required to objectively and comprehensively dissect vaccine induced Fc effector functions, in order to identify protective antibody immune features.

\section{Hierarchical layers of antibody features modulate Fc effector functions}

Upon vaccination, humoral diversification forms the foundation of the humoral immune response, that aims to target foreign antigen as broadly and effectively as possible [32]. This response gives rise to polyclonal antibodies that are tuned by genetic, molecular and environmental factors to selectively respond in a pathogen-specific manner. The combined activity of these polyclonal pools is determined by a cumulative framework of antibody features; specificities dictated by the antibody Fragment antigen binding (Fab) region and $\mathrm{Fc}$ receptor binding capacity directed by the antibody Fragment crystalizable $(\mathrm{Fc})$ region [33]. For example, a subset of vaccineinduced antibodies may work in a cohesive, collaborative fashion, forming high avidity immune complexes with a preference towards activating Fcy Receptor engagement and hence exhibiting a more functional Fc effector profile. However, a vaccine might also simultaneously induce antibodies with competing features, potentially blocking immune complex formation or reducing Fcy Receptor engagement, thus potentially hindering Fc effector functions. Using the earlier described non-protective VAX003 vaccine as an example: VAX003 vaccination induced high levels of total HIV-specific IgG antibodies, however with proportionately elevated levels of weakly functional HIVspecific IgG4, that competed for antigen occupancy with more functional HIV-specific antibody subclasses (e.g. IgG1 and IgG3), overall resulting in a less functional immune response [30, 31]. However, depletion of IgG4 antibodies from IgG samples, resulted in significantly higher functional antibody responses [31]. Similarly, depletion of the more functional HIV-specific IgG3 from vaccine samples resulted in a decrease in function. Thus collectively, functional antibody responses are the result of a dynamic equilibrium of the combination of these enhancing and competitive inhibitory antibody profiles, and the immune environment in which these antibodies are placed. Systems serology therefore aims to comprehensively examine as many of these antibody features as possible, in order to assess the mechanisms behind specific Fc effector responses and identify the most important antibody features required for superior Fc functional activity or protection induced by vaccination, pinpointing the key targets for future experimental validation and additional quantitative models. 


\section{Systems serology}

Systems tools have revolutionized our understanding of basic immune processes including immune responses to vaccination, disease and immune development. Key to this developing area of research, is the comprehensive and unbiased collection of data to capture as much information as possible to inform and identify previously unappreciated processes in biology. This field has lead to the development of many OMIC tools including genomics (the whole molecular code) [34, 35], transcriptomics (the whole transcriptional code) [36], proteomics (the building blocks and communicators within the system) [37] and metabolomics (the nutritional/activity state of the system) [38]. While all these tools provided deep information at the cellular level, they provided little resolution related to the humoral immune response, that is composed of polyclonal antibodies that can work together to modulate a range of different anti-pathogenic functions. Thus Systems serology was designed to address this area, with the specific aim to capture and assimilate as much information as possible related to the modulation of functional humoral immune responses.

Systems serology consists of a fusion of high throughput experimental techniques aimed at dissecting the antibody features and functions, followed by a range of computational methods to help mine through and provide an unprecedented depth of understanding to the profiled antibodies. Simplistically, the experimental assays used to interrogate antibodies can be divided into (1) Biophysical assays (Summarized in Table 1) and (2) Functional assays (Summarized in Table 2). Biophysical assays reflect the immediate genetic and molecular constraints of vaccine-induced antibodies that dictate antigen recognition and $\mathrm{Fc} \gamma$ Receptor engagement. In parallel, functional assays are used to examine, in vitro, the functional potential of these antibodies, which is dependent upon the availability of specific effector cells or immune environments. Upon compilation of these extensive datasets, both supervised and unsupervised machine learning computational techniques, commonly used in Systems biology, can be applied to allow for the examination of the multiple layers of antibody information, in order to help decipher and identify important features associated with protection and/or Fc functional activity.

\section{Biophysical antibody features in HIV vaccines and infection Antibody epitope recognition}

Vaccine-induced humoral immune responses can produce a multitude of polyclonal antibodies, that have the potential to target an extensive array of conformational and linear epitopes, which can be detected by multiple

Table 1 Biophysical antibody profiles

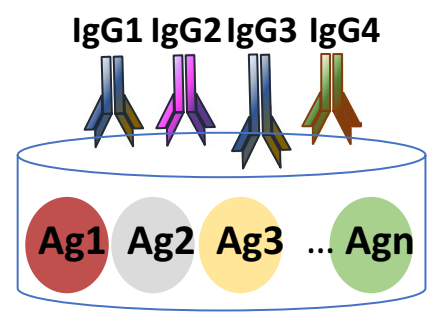

Antigen target and subclassing

\section{Biophysical}

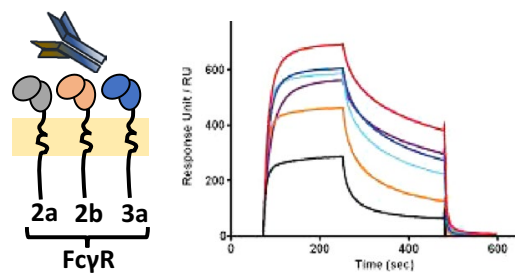

Fc-receptor and Ag Affinity

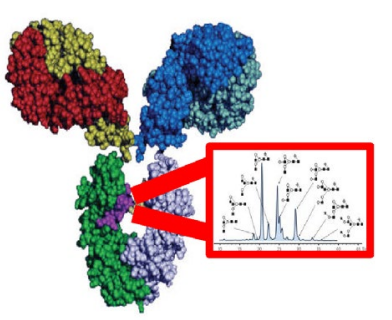

Glycans

\begin{tabular}{|c|c|c|c|c|c|c|c|c|}
\hline \multirow{2}{*}{$\begin{array}{l}\text { Fragment } \\
\text { Feature }\end{array}$} & \multicolumn{3}{|l|}{ Fab } & \multicolumn{5}{|l|}{ Fc } \\
\hline & Antigen target & Epitope target & Antigen affinity & Isotype & Subclass & Glycans & FcR/C'binding & FcR affinity \\
\hline $\begin{array}{c}\text { Examples of } \\
\text { measure- } \\
\text { ments }\end{array}$ & $\begin{array}{l}\text { gp120 gp41 } \\
\text { p24 }\end{array}$ & $\begin{array}{l}\text { Scaffolds } \\
\text {-V1V2 } \\
\text {-SOSIP } \\
\text {-linear peptides }\end{array}$ & $\begin{array}{l}\text { Dissociation } \\
\text { constant } \\
\text { (k-off) }\end{array}$ & $\begin{array}{l}\lg A \\
\lg M \\
\lg G\end{array}$ & $\begin{array}{l}\lg G 1 \\
\lg G 2 \\
\lg G 3 \\
\lg G 4 \\
\lg A 1 \\
\lg A 2\end{array}$ & $\begin{array}{l}\text { 30 glycan } \\
\text { combinations } \\
\text { Eg. Fucose, } \\
\text { bisecting } \\
\text { GLNAc, Galac- } \\
\text { tose, Sialic } \\
\text { Acid }\end{array}$ & $\begin{array}{l}\text { Cla } \\
\text { MBL } \\
\text { FcyRl } \\
\text { FcyRlla } \\
\text { FcyRIlb } \\
\text { FcyRIIla } \\
\text { FcyRIIlb }\end{array}$ & $\begin{array}{l}\text { Equilibrium } \\
\text { constants } \\
\text { (KD) }\end{array}$ \\
\hline $\begin{array}{l}\text { Examples } \\
\text { of Assays }\end{array}$ & $\begin{array}{l}\text { Multiplex } \\
\text { ELISAs }\end{array}$ & $\begin{array}{l}\text { Multiplex } \\
\text { ELISAs } \\
\text { ICS }\end{array}$ & $\begin{array}{l}\text { SPR } \\
\text { Chaotrope }\end{array}$ & $\begin{array}{l}\text { Multiplex } \\
\text { ELISAs }\end{array}$ & $\begin{array}{l}\text { Multiplex } \\
\text { ELISAs }\end{array}$ & $\begin{array}{l}\text { Mass Spec } \\
\text { HPLC } \\
\text { CE } \\
\text { Multiplex }\end{array}$ & $\begin{array}{l}\text { ELISA } \\
\text { Multiplex }\end{array}$ & SPR \\
\hline References & [104] & {$[31,40]$} & {$[105]$} & [104] & [104] & {$[53,87,106]$} & {$[44,87]$} & {$[105,107]$} \\
\hline
\end{tabular}


Table 2 Profiling functional Fc effector functions

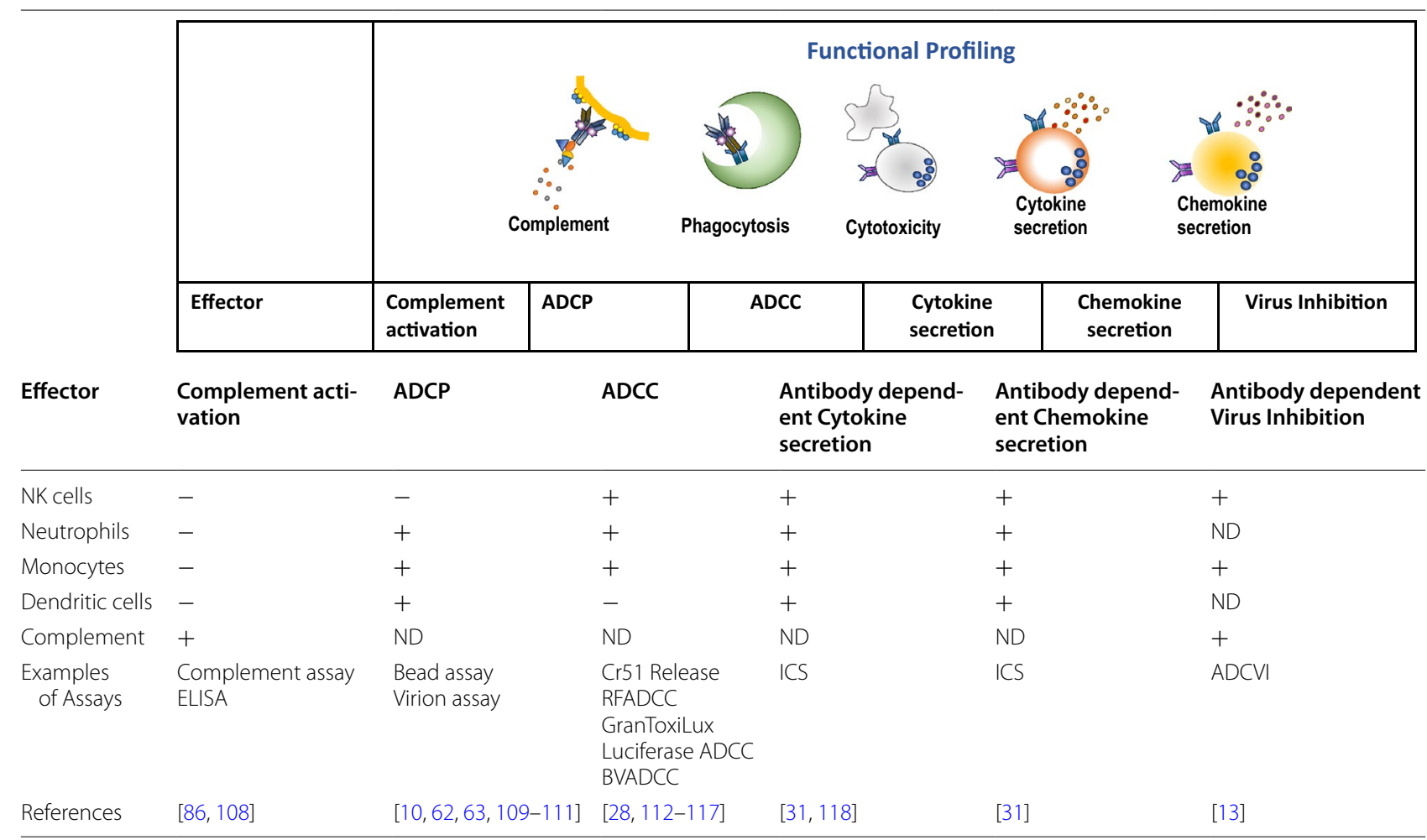

methods (Table 1-left columns). In the case of HIV vaccination, the required epitopes can be even more complex, as sequence variation across different strains and clades can alter not only epitope recognition but also ENV protein glycosylation patterns $[39,40]$. In this context, the uniqueness and strength of functional Fc-mediated antibodies lies in their ability to target a large array of epitopes, beyond the few limited neutralizing antibody sites [41], thus potentially allowing for the exploitation of alternative conserved sequences as epitopes $[40,42]$. It is also due to the ability of non-neutralizing antibodies to target a diverse array of epitopes, that functional antibodies may potentially have greater breadth of recognition across different HIV clades [43, 44], an important measure to assess, due to the extreme diversity of HIV strains. Of interest, ADCC activity has also been observed against various other highly conserved HIV viral antigens including gag, pol and the accessory proteins, and has been linked to slower disease progression [45-47], however, due to the intracellular location of many of these epitopes, their relevance to protection from infection is still unclear. In addition to the nature of the epitope recognized, both the strength of antibody engagement with the antigen [48] and epitope availability/masking can impact immune complex formation [49].
Together, it can be hypothesized that higher affinity antibodies, recognizing readily available/conserved epitopes, will form prolonged immune complexes and hence have increased opportunities for $\mathrm{F} c \gamma$ receptor engagement.

\section{Antibody Fc structure}

Despite its name, an antibody's Fragment crystalizable $(\mathrm{Fc})$, or constant region can also be highly modulated [33]. These changes can influence an antibody's ability to bind and engage $\mathrm{Fc}_{\mathrm{c}}$ receptors present on innate immune cells or other immune components, such as complement. Binding ability can be modulated through small biophysical differences ranging from isotypes (e.g. IgG, IgA, IgM, IgE, IgD) or subclasses (e.g. IgG1-4) [50], to single amino acid polymorphisms [51], small glycan modifications $[52,53]$ and immune complex size [54], that collectively can contribute to differences in Fc-FcR binding ability. Several high throughput standardized assays have been developed to allow for the in-depth assessment for these features (Summarized in Table 1- right columns). In the context of HIV, multiple studies have demonstrated the importance of subclass, isotype and glycosylation state for control of disease and/or protection [30,31, 55-57]. For example, the results of the RV144 immune correlates analysis has suggested that serum IgA levels may be 
detrimental to vaccine efficacy [25], potentially through competition of more functional vaccine-induced IgG, capable of mediated ADCC [58]. However, in contrast, results from a non-human primate passive antibody immunization study, demonstrate that dimeric IgA1 was superior to both IgA2 and IgG1 in providing protection against SHIV mucosal infection [59]. Overall these data suggest that IgA may have both protective and detrimental effects on HIV immunity, dependent on its location.

\section{Antibody dependent functional responses}

Prior to the results of the RV144 trial, the majority of functional Fc-mediated antibody research focused upon ADCC responses through assays that detected the lysis of target cells or inhibition of viral replication [13, 60]. Many of the assays were highly complex, difficult to standardize, and time consuming, requiring the use of radioactive cells such as the chromium release assay or virus-infected primary target cells [61]. However in the past decade, several high throughput ADCC and other functional Fc-mediated assays have been developed, allowing us to probe multiple other non-neutralizing antibody functions (Table 2). These include, but are not limited to, antibody dependent complement dependent cytotoxicity (ADCDC) [55], antibody dependent cellular (or viral) phagocytosis (ADCP) [62, 63], antibody mediated effector cell cytokine and chemokine secretion [64] along with antibody dependent cellular viral inhibition (ADCVI) [13]. Antibodies also have the capacity to induce multiple other effector functions including, but not limited to antibody dependent enzymatic release/respiratory burst [21] and antibody mediated mucus trapping [65]; however, high throughput qualitative robust assays to assess these functions in HIV are still in development.

\section{Fcy receptor and effector cell diversity}

Fc-functional immune responses are often dictated by the innate immune effector cell that is being activated and its respective $\mathrm{F} c \gamma \mathrm{R}$ repertoire. It is for that reason that earlier ADCC studies commonly examined NK cell-specific antibody function, due to the fact that NK cells primarily express a single activating Fc $\gamma$ RIIIa (CD16a) allowing for easier interpretation of results [66]. However, three distinct classes of Fc $\gamma$ Rs are expressed on human innate immune cells, with varying levels of expression dependent on cell type. These include FcyRI, Fc $\gamma \mathrm{IIa} / \mathrm{b} / \mathrm{c}$, and FcyIIIa/b, which bind the different IgG subclasses with varying proficiency, and can cause either activation or inhibition of the effector cell [50]. Furthermore, a range of $F c \gamma R$ polymorphisms have been identified in humans, some of which have greater Fc binding affinity and hence are associated with enhanced Fc effector functional capacity. For example, individuals carrying the high affinity FcyRIIa H131 polymorphism, most commonly associated with enhanced ADCP, have positive outcomes in both cancer [67] and infectious disease studies, including HIV $[68,69]$. In contrast, the Fc $\gamma$ RIIIa V158 polymorphism, associated with enhanced ADCC functionality, has been linked with better outcomes within the monoclonal therapeutics cancer field [70, 71]. Conversely, however, this same polymorphism has been associated with HIV disease progression [72] and the lack of protection from the VAX004 vaccine trial [73]. Thus assays able to capture the functional activity of antibodies through multiple Fc $\gamma$ Rs may provide enhanced resolution of the vast repertoire of functions that may be leveraged to control/kill HIV, while assays utilizing individual FcyRs provide an opportunity to critically capture a quantitative view of a specific antibody function. Furthermore, $\mathrm{Fc} \gamma \mathrm{R}$ expression profiles may change with infection status and site of infection [74], all which must be considered in the process of establishing meaningful assays for the analysis of functional humoral immune responses, as these Fc $\gamma$ Rs compete on the surface of innate immune cells for immune complex binding. For many of the described Fc effector assays, specific Fc $\gamma R$ bearing innate immune cells can be isolated and their $\mathrm{Fc} \gamma \mathrm{R}$ polymorphisms and expression levels can be determined, so that the Fc-mediated immune responses can examined and later reconstituted in a biologically meaningful manner.

\section{Assay selection and technical considerations}

As with all experimental assays, standardization and optimization is critical to enable accurate cross-study comparisons. Control samples are essential for validation and quality control. Furthermore, sample and control replicates should be completed for all assays to confirm assay reliability, and data accuracy. Data analysis techniques can be utilized to confirm assay and data quality, these include determining signal to noise ratios or calculating the $\mathrm{Z}$ score [75].

It is important to note that a more robust, optimized assay does not necessarily reflect biological relevance. For example many of the most reproducible functional antibody assays utilize cell lines that are representative of functional immune responses [62, 76]. There are multiple advantages to these assays including high throughput data quality and repeatability on an intralaboratory basis. However it should be acknowledged that they often do not represent the biological diversity as observed when using assays that utilize primary cells [77]. In contrast, assays that involve the isolation and use of primary Fc $\gamma \mathrm{R}$ receptor cells, especially from mucosal tissues to assess for functional humoral responses, may be highly biologically relevant, however currently, robust high throughput technologies with the capacity to assess 
these responses are less developed. Thus assay selection may also take into consideration current assay technology constraints and biological significance.

The full spectrum of biophysical and functional assays should ideally be collected from all samples, thus allowing for a sweeping assessment and the application of computational approaches to the entire cohort. While admittedly it is not always feasible or practical to collect entire data sets from large cohorts, estimating smaller sample sizes for reliable analysis should be carefully considered prior to experimental data collection, as this can be influenced by multiple factors, including the computational methods applied and dimensionality of the data (e.g. number antibody features and functions) [78].

\section{Computational techniques}

When all measurements are compiled, systems-level computational analysis can then be applied to probe for mechanistic insights or antibody biomarkers of protection. A variety of different "machine learning" or datadriven computational approaches have been previously applied to Systems biology and Systems vaccinology (reviewed $[79,80]$ ) and more recently Systems serology [81]. These approaches are broadly classified as 'unsupervised' and 'supervised' approaches. 'Unsupervised' approaches explore the compiled datasets, without predefining groups to base the analysis upon, thus allowing for the identification of natural similarities or "clusters" within the data. A major advantage of unsupervised systemic examination of broad Fc effector profiles, is the ability to comprehensively explore the mechanisms behind specific functions or correlates of protection in an unbiased fashion, potentially revealing novel linkages that would not normally be identified by traditional approaches. Previous unsupervised approaches that have been successfully applied in Systems serology research include principal component analysis (PCA) and correlation networks [82-84].

In contrast, 'supervised' approaches include the addition of predefined groups or classifications, from which the analysis is based, with the goal of identifying key parameters associated with the predefined groups or "classes". In the context of Systems serology, these groups may be related to a specific advantageous Fc effector function (e.g. ADCC or ADCP etc.) or clinical outcome (e.g. protective versus non-protective vaccine), with the aim to identify novel correlates of protection or key antibody features associated with Fc effector functions. Supervised analytical techniques that have previously been applied to Systems serology include partial least squares discriminant analysis (PLSDA) and decision tree analyses [82, 84-86].
In addition, current high throughput assays used to measure antibody structure and function can generate tens and more often hundreds of data points per sample (for example, Fc/isotype multiplex arrays or peptide epitope mapping) [87]. The strength of this comprehensive approach is that all samples are assessed in an unbiased manner for as many functional antibody features as possible. The downside of this analysis is that many of these antibody features and functions have the potential to be highly correlated with each other, thus highlighting multiple features and often resulting in over complex models. This can create overwhelmingly large data sets, where the total number of antibody measurements can outweigh the number of samples tested. Thus feature selection methods are useful for minimizing the number of selected features, correcting for the effect of over fitting data, which can improve model performance and help reduce complexity of the data (reviewed in $[88,89]$ ).

Overall, application of these machine learning computational techniques in Systems serology research, has the ability to highlight the most critical associations between antibody features and functions with protection from HIV infection, thus becoming a highly targeted and comprehensive hypothesis driving tool that can accelerate our understanding of the humoral immune system, and help to identify key areas of interest for further experimentation, vaccine testing or exploration by additional quantitative models.

\section{Systems approaches for the analysis of functional antibody responses in human vaccination}

Previous application of Systems biology and vaccinology approaches has resulted in the identification of genetic or immune signatures that correlate with vaccine efficacy for yellow fever [90], influenza [91] and malaria [92, 93]. These predictive signatures can be used to identify novel mechanistic insights and aid the development of future vaccine strategies, while also serving as valuable biomarkers to screen for vaccine efficacy in future trials.

In our application of Systems serology to different human HIV vaccines [84], we utilized a variety of modelling and data clustering techniques to examine the antibody profiles of the moderately protective RV144 trial (ALVAC and AIDSVAX B/E [24]) and two nonefficacious HIV vaccine trials: VAX003 (AIDSVAX B/E [29]); and HVTN204 (DNA/rAD5 [94]). Importantly, application of both unsupervised and supervised analysis approaches were able to differentiate between AIDSVAX B/E protein containing vaccines (i.e. RV144 and VAX003) and DNA/rAD5 vaccination (HVTN204). Furthermore, in a supervised analysis that applied LASSO [95] (least absolute feature shrinkage and selection operator) for 
feature selection followed by PLSDA [96] (partial leastsquares discriminant analysis), we were able to clearly differentiate between RV144 and the non-efficacious VAX003 trial samples, reconfirming previous studies that associated RV144 with enhanced levels of IgG3 and VAX003 with an elevated IgG4 signature [30,31].

A similar supervised LASSO and PLSDA approach was applied to RV144 recipients separated into those with high or low V1V2 responses, as a representation of low versus high risk of infection, based on the original immune correlate analysis [25]. High IgG V1V2 responder profiles, with predicted low risk of infection, were associated with high levels of HIV-specific IgG1 along with multiple or potentially "polyfunctional" Fc effector functions including ADCP, ADCC, and antibody dependent NK cell activation. Follow up studies now also suggest that high V1V2 responders not only have enhanced Fc functionality, but may also have increased ADCC epitope breadth [44]. In contrast, low IgG V1V2 responders, predicted to have a higher risk of infection, were associated with HIV-specific IgA, recapitulating earlier immune correlate studies [25]. Of interest, repetition of this analysis comparing high and low IgG3-V1V2 responders (which was also detected to be a correlate of protection [30]), associated high IgG3-V1V2 responders with activating Fc $\gamma$ RIIa, required for ADCP, and Fc $\gamma$ RIIIa, which is critical for NK cell activation and ADCC. These results reinforce the importance of polyfunctional Fceffector functions. However, contrary to the total IgGV1V2 analysis, IgA was not identified as a correlate of the low IgG3 V1V2 responder profile, suggesting that IgA responses may exert varying degrees of modulation/ interference with Fc effector responses. Further studies to dissect the divergent roles of IgA, potentially in a V1V2 subclass specific manner, may be warranted.

Functional humoral immune responses are induced through the engagement of immune complexes that consist of varying antibody composition, antigen specificity and $\mathrm{Fc} \gamma \mathrm{R}$ engagement. Thus the interactions required for Fc functions are an ideal model for the application of network and pathway analyses that are commonly applied in bioinformatics analyses (reviewed in [97, 98]). These approaches are useful as they allows us to simultaneously examine the connectivity between different antibody functions and features to examine mechanisms behind antibody functional activity, in an unbiased, objective manner. These interactions are often displayed as networks that illustrate the degree of connectivity between different features. Examination of the structural organization and topology of these biological networks can provide us with information behind key interactions that regulate a specific functional immune response.
Application of correlation networks analysis to the different vaccine trials revealed extremely different network topographies or 'humoral fingerprints'. Importantly the connectivity analysis using RV144 samples reiterated earlier PLSDA results, demonstrating that ENV-specific IgG1 and IgG3 responses were interconnected with multiple antibody effector functions including ADCC, ADCP and $A D C D C$, which was not observed for the other nonefficacious vaccine trials.

\section{Systems serology approaches in non-human primate models efficacy trials}

Similar Systems serology approaches have also been applied to several SIV and SHIV vaccine trials [86, 99, 100]. A combination of Systems biology and Systems serology analyses was applied to a non-human primate (NHP) RV144-like vaccine and challenge study consisting of an ALVAC prime followed gp120 protein boost vaccine strategy, comparing the adjuvants Alum and MF-59. Systems analysis of this study was able to associate mucosal innate lymphoid cells producing IL-17, RAS activation, and mucosal V2 antibodies with delayed acquisition of infection [100]. A second NHP vaccine study, consisting of Ad26 prime followed by ENV protein boost, applied similar systems serology techniques and associated the observed 50\% protection from repeated SIV challenges with polyfunctional Fc effector functions including ADCP, ADCC, ADCD and antibody mediated NK cell activation [86]. Collectively, these NHP systems serology studies reinforce the results of the previous RV144 immune correlates analysis [25] and in combination with the RV144 Systems serology study [84], suggest that future HIV vaccines capable of eliciting polyfunctional Fc effector profiles, with a preferential upregulation of IgG3 subclasses and high levels of $\mathrm{V} 2$ antibodies may be able to reduce the risk of HIV infection.

In the future, additional Systems serology analysis of vaccine trials in NHP, with known efficacy will provide us additional opportunities to identify correlates of protection. Importantly, NHP vaccine trials provide us with the unique opportunity to dissect responses to a deeper degree, often not possible in human vaccination, both by way of sample collection and information about the challenge virus [101]. While there are significant differences in both FcyR and IgG biology between humans and NHP, dissecting the NHP Fc $\gamma \mathrm{R}$ and Immunoglobulin $\mathrm{H}$ locus is an area of growing intense research [102]. As our understanding of this field grows, we may be able to better build parallels between NHP and human protective responses that will allow us to build predictive models that may help guide the HIV vaccine field. 


\section{Systems serology: A constantly expanding platform}

It is important to note that the technologies available to measure biophysical antibody features and functions are constantly evolving to allow for the assessment of more diverse cell types, cellular environments, receptors and antigen specificities. No doubt, in the future, many other high throughput assays will be developed to allow for advanced measurements of antibody features. Next-generation sequencing and bioinformatics have already enabled probing of the antibody repertoire and greater understanding of the evolution of broadly neutralizing antibodies, and these techniques could be modified and applied to explore the evolution of polyfunctional non-neutralizing or V1V2 antibodies [103]. Similarly, new technologies are being developed to better examine mucosal antibody features, as well as functional assays that better represent in vivo Fc-functional responses from different effector sites such as blood, gut, and reproductive mucosal environments. Additionally, a multitude of alternative analytical approaches could be applied to qualitatively evaluate vaccines responses. Application of Systems serology is not limited to HIV vaccinology, but could potentially be applied to numerous other infectious and autoimmune diseases [83], or could be used to examine differences in humoral immune responses amongst individuals of differing gender, age or ethnicity. There is no doubt that Systems serology is still in its early developmental stages and will continue to evolve over time to capture broader Fc-effector profiling and improved multi-dimensional analytic approaches, providing us with an increasingly comprehensive understanding of the humoral immune response required for the identification of the most desirable vaccine profiles in order to guide the rational design of future HIV vaccine candidates.

\section{Authors' contributions}

AWC and GA prepared and edited the manuscript. Both authors read and approved the final manuscript.

\section{Acknowledgements}

We are grateful to Dr. Jennifer Juno and Prof Stephen Kent for their support and comments.

\section{Competing interests}

The authors declare that they have no competing interests.

\section{Availability of data and materials}

Data sharing is not applicable to this article as no datasets were generated or analysed during the current study.

\section{Funding}

This work was supported by the Australian National Health \& Medical Research Center (AWC), the American Foundation for AIDS Research (amfAR) Mathilde Krim Fellowship (AWC), the Bill and Melinda Gates Foundation (GA), NIAID $(G A)$, the Ragon Institute (GA), and NIH Harvard Center for AIDS Research (GA).

\section{Publisher's Note}

Springer Nature remains neutral with regard to jurisdictional claims in published maps and institutional affiliations.

Received: 4 August 2017 Accepted: 27 November 2017

Published online: 21 December 2017

\section{References}

1. Plotkin SA. Correlates of protection induced by vaccination. Clin Vaccine Immunol. 2010;17:1055-65.

2. Jack AD, Hall AJ, Maine N, Mendy M, Whittle HC. What level of hepatitis B antibody is protective? J Infect Dis. 1999;179:489-92.

3. Frazer I. Correlating immunity with protection for HPV infection. Int J Infect Dis. 2007;11(Suppl 2):S10-6.

4. Faden H, Modlin JF, Thoms ML, McBean AM, Ferdon MB, Ogra PL. Comparative evaluation of immunization with live attenuated and enhanced-potency inactivated trivalent poliovirus vaccines in childhood: systemic and local immune responses. J Infect Dis. 1990;162:1291-7.

5. Wheatley AK, Kent SJ. Prospects for antibody-based universal influenza vaccines in the context of widespread pre-existing immunity. Expert Rev Vaccines. 2015;14:1227-39.

6. Mason RA, Tauraso NM, Spertzel RO, Ginn RK. Yellow fever vaccine: direct challenge of monkeys given graded doses of 17D vaccine. Appl Microbiol. 1973:25:539-44.

7. Lee LH, Frasch CE, Falk LA, Klein DL, Deal CD. Correlates of immunity for pneumococcal conjugate vaccines. Vaccine. 2003;21:2190-6.

8. Kilgore PE, Salim AM, Zervos MJ, Schmitt HJ. Pertussis: microbiology, disease, treatment, and prevention. Clin Microbiol Rev. 2016;29:449-86.

9. Pulendran B, Ahmed R. Immunological mechanisms of vaccination. Nat Immunol. 2011;12:509-17.

10. Hessell AJ, Hangartner L, Hunter M, Havenith CE, Beurskens FJ, Bakker JM, Lanigan CM, Landucci G, Forthal DN, Parren PW, et al. Fc receptor but not complement binding is important in antibody protection against HIV. Nature. 2007;449:101-4.

11. Barouch DH, Stephenson KE, Borducchi EN, Smith K, Stanley K, McNally AG, Liu J, Abbink P, Maxfield LF, Seaman MS, et al. Protective efficacy of a global HIV-1 mosaic vaccine against heterologous SHIV challenges in rhesus monkeys. Cell. 2013;155:531-9.

12. Bournazos S, Klein F, Pietzsch J, Seaman MS, Nussenzweig MC, Ravetch JV. Broadly neutralizing anti-HIV-1 antibodies require Fc effector functions for in vivo activity. Cell. 2014;158:1243-53.

13. Forthal DN, Landucci G, Daar ES. Antibody from patients with acute human immunodeficiency virus (HIV) infection inhibits primary strains of HIV type 1 in the presence of natural-killer effector cells. J Virol. 2001;75:6953-61.

14. DiLillo DJ, Tan GS, Palese P, Ravetch JV. Broadly neutralizing hemagglutinin stalk-specific antibodies require FcgammaR interactions for protection against influenza virus in vivo. Nat Med. 2014;20:143-51.

15. Jegerlehner A, Schmitz N, Storni T, Bachmann MF. Influenza A vaccine based on the extracellular domain of M2: weak protection mediated via antibody-dependent NK cell activity. J Immunol. 2004;172:5598-605.

16. KohI S, Loo LS, Pickering LK. Protection of neonatal mice against herpes simplex viral infection by human antibody and leukocytes from adult, but not neonatal humans. J Immunol. 1981;127:1273-5.

17. Kohl S, Loo LS. Protection of neonatal mice against herpes simplex virus infection: probable in vivo antibody-dependent cellular cytotoxicity. J Immunol. 1982:129:370-6.

18. Warfield KL, Swenson DL, Olinger GG, Kalina WV, Aman MJ, Bavari S. Ebola virus-like particle-based vaccine protects nonhuman primates against lethal Ebola virus challenge. J Infect Dis. 2007;196(Suppl 2):S430-7.

19. Bouharoun-Tayoun H, Oeuvray C, Lunel F, Druilhe P. Mechanisms underlying the monocyte-mediated antibody-dependent killing of Plasmodium falciparum asexual blood stages. J Exp Med. 1995;182:409-18.

20. Shi J, Mclntosh RS, Pleass RJ. Antibody- and Fc-receptor-based therapeutics for malaria. Clin Sci (Lond). 2006:110:11-9.

21. Joos C, Marrama L, Polson HE, Corre S, Diatta AM, Diouf B, Trape JF, Tall A, Longacre S, Perraut R. Clinical protection from falciparum malaria 
correlates with neutrophil respiratory bursts induced by merozoites opsonized with human serum antibodies. PLoS ONE. 2010;5:e9871.

22. McCoy LE, Weiss RA. Neutralizing antibodies to HIV-1 induced by immunization. J Exp Med. 2013;210:209-23.

23. Excler JL, Robb ML, Kim JH. Prospects for a globally effective HIV-1 vaccine. Am J Prev Med. 2015;49:S307-18.

24. Rerks-Ngarm S, Pitisuttithum P, Nitayaphan S, Kaewkungwal J, Chiu J, Paris R, Premsri N, Namwat C, de Souza M, Adams E, et al. Vaccination with ALVAC and AIDSVAX to prevent HIV-1 infection in Thailand. N Engl J Med. 2009;361:2209-20.

25. Haynes BF, Gilbert PB, McElrath MJ, Zolla-Pazner S, Tomaras GD, Alam SM, Evans DT, Montefiori DC, Karnasuta C, Sutthent R, et al. Immunecorrelates analysis of an HIV-1 vaccine efficacy trial. New Engl J Med. 2012;366:1275-86.

26. Zolla-Pazner S, deCamp A, Gilbert PB, Williams C, Yates NL, Williams WT, Howington R, Fong Y, Morris DE, Soderberg KA, et al. Vaccine-induced IgG antibodies to V1V2 regions of multiple HIV-1 subtypes correlate with decreased risk of HIV-1 infection. PLoS ONE. 2014;9:e87572.

27. von Bubnoff A. Antibodies: beyond neutralization. IAVI Rep. 2010;14:8-12.

28. Huang Y, Ferrari G, Alter G, Forthal DN, Kappes JC, Lewis GK, Love JC, Borate B, Harris L, Greene K, et al. Diversity of antiviral IgG effector activities observed in HIV-infected and vaccinated subjects. J Immunol. 2016;197:4603-12.

29. Pitisuttithum P, Gilbert P, Gurwith M, Heyward W, Martin M, van Griensven F, Hu D, Tappero JW, Choopanya K. Randomized, double-blind, placebo-controlled efficacy trial of a bivalent recombinant glycoprotein 120 HIV-1 vaccine among injection drug users in Bangkok, Thailand. J Infect Dis. 2006;194:1661-71.

30. Yates NL, Liao HX, Fong Y, deCamp A, Vandergrift NA, Williams WT, Alam SM, Ferrari G, Yang ZY, Seaton KE, et al. Vaccine-induced Env V1-V2 lgG3 correlates with lower HIV-1 infection risk and declines soon after vaccination. Sci Transl Med. 2014;6:228ra239.

31. Chung AW, Ghebremichael M, Robinson H, Brown E, Choi I, Lane S, Dugast AS, Schoen MK, Rolland M, Suscovich TJ, et al. Polyfunctional Fceffector profiles mediated by IgG subclass selection distinguish RV144 and VAX003 vaccines. Sci Transl Med. 2014;6:228ra238.

32. Neuberger MS. Antibody diversification by somatic mutation: from Burnet onwards. Immunol Cell Biol. 2008;86:124-32.

33. Chung AW, Alter G. Dissecting the antibody constant region protective immune parameters in HIV infection. Future Virol. 2014;9:397-414.

34. Koboldt DC, Steinberg KM, Larson DE, Wilson RK, Mardis ER. The nextgeneration sequencing revolution and its impact on genomics. Cell. 2013;155:27-38.

35. Fellay J, Shianna KV, Telenti A, Goldstein DB. Host genetics and HIV-1: the final phase? PLoS Pathog. 2010;6:e1001033.

36. Sorek R, Cossart P. Prokaryotic transcriptomics: a new view on regulation, physiology and pathogenicity. Nat Rev Genet. 2010;11:9-16.

37. Pandey A, Mann M. Proteomics to study genes and genomes. Nature. 2000;405:837-46.

38. Spratlin JL, Serkova NJ, Eckhardt SG. Clinical applications of metabolomics in oncology: a review. Clin Cancer Res. 2009;15:431-40.

39. Wei X, Decker JM, Wang S, Hui H, Kappes JC, Wu X, Salazar-Gonzalez JF, Salazar MG, Kilby JM, Saag MS, et al. Antibody neutralization and escape by HIV-1. Nature. 2003:422:307-12.

40. Chung AW, Isitman G, Navis M, Kramski M, Center RJ, Kent SJ, Stratov I. Immune escape from HIV-specific antibody-dependent cellular cytotoxicity (ADCC) pressure. Proc Natl Acad Sci USA. 2011;108:7505-10.

41. Sadanand S, Suscovich TJ, Alter G. Broadly neutralizing antibodies against HIV: new insights to inform vaccine design. Annu Rev Med. 2016:67:185-200.

42. Bonsignori M, Pollara J, Moody MA, Alpert MD, Chen X, Hwang KK, Gilbert PB, Huang Y, Gurley TC, Kozink DM, et al. Antibody-dependent cellular cytotoxicity-mediating antibodies from an HIV-1 vaccine efficacy trial target multiple epitopes and preferentially use the $\mathrm{VH} 1$ gene family. JVirol. 2012;86:11521-32.

43. Madhavi V, Wren LH, Center RJ, Gonelli C, Winnall WR, Parsons MS, Kramski M, Kent SJ, Stratov I. Breadth of HIV-1 Env-specific antibodydependent cellular cytotoxicity: relevance to global HIV vaccine design. AIDS. 2014;28:1859-70.
44. McLean MR, Madhavi V, Wines BD, Hogarth PM, Chung AW, Kent SJ. Dimeric Fcgamma Receptor Enzyme-Linked Immunosorbent Assay To Study HIV-Specific Antibodies: a New Look into Breadth of Fcgamma Receptor Antibodies Induced by the RV144 Vaccine Trial. J Immunol. 2017;199(2):816-26.

45. Wren LH, Chung AW, Isitman G, Kelleher AD, Parsons MS, Amin J, Cooper DA, Stratov I, Navis M, Kent SJ. Specific antibody-dependent cellular cytotoxicity responses associated with slow progression of HIV infection. Immunology. 2013;138:116-23.

46. Isitman G, Chung AW, Navis M, Kent SJ, Stratov I. Pol as a target for antibody dependent cellular cytotoxicity responses in HIV-1 infection. Virology. 2011;412:110-6.

47. Grunow R, Franke L, Hinkula J, Wahren B, Fenyo EM, Jondal M, von Baehr R. Monoclonal antibodies to p24-core protein of HIV-1 mediate ADCC and inhibit virus spread in vitro. Clin Diagn Virol. 1995;3:221-31.

48. Madhavi V, Wines BD, Amin J, Emery S, Lopez E, Kelleher A, Center R, Hogarth PM, Chung AW, Kent SJ, Stratov I. HIV-1 Env- and Vpu-specific antibody-dependent cellular cytotoxicity responses associated with elite control of HIV. J Virol. 2017;91:e00700-17.

49. Lewis GK, Finzi A, DeVico AL, Pazgier M. Conformational masking and receptor-dependent unmasking of highly conserved Env epitopes recognized by non-neutralizing antibodies that mediate potent ADCC against HIV-1. Viruses. 2015;7:5115-32.

50. Hogarth PM, Pietersz GA. Fc receptor-targeted therapies for the treatment of inflammation, cancer and beyond. Nat Rev Drug Discov. 2012:11:311-31.

51. Moraru M, Black LE, Muntasell A, Portero F, Lopez-Botet M, Reyburn $H T$, Pandey JP, Vilches C. NK cell and Ig interplay in defense against herpes simplex virus type 1: epistatic interaction of CD16A and IgG1 allotypes of variable affinities modulates antibody-dependent cellular cytotoxicity and susceptibility to clinical reactivation. J Immunol. 2015;195:1676-84.

52. Shields RL, Lai J, Keck R, O'Connell LY, Hong K, Meng YG, Weikert SH, Presta LG. Lack of fucose on human IgG1 N-linked oligosaccharide improves binding to human Fcgamma RIII and antibody-dependent cellular toxicity. J Biol Chem. 2002;277:26733-40.

53. Chung AW, Crispin M, Pritchard L, Robinson H, Gorny MK, Yu X, BaileyKellogg C, Ackerman ME, Scanlan C, Zolla-Pazner S, Alter G. Identification of antibody glycosylation structures that predict monoclonal antibody Fc-effector function. AIDS. 2014;28:2523-30.

54. Lux A, YuX, Scanlan CN, Nimmerjahn F. Impact of immune complex size and glycosylation on IgG binding to human FcgammaRs. J Immunol. 2013;190:4315-23.

55. Ackerman ME, Mikhailova A, Brown EP, Dowell KG, Walker BD, BaileyKellogg C, Suscovich TJ, Alter G. Polyfunctional HIV-Specific antibody responses are associated with spontaneous HIV control. PLoS Pathog. 2016;12:e1005315.

56. Banerjee K, Klasse PJ, Sanders RW, Pereyra F, Michael E, Lu M, Walker BD, Moore JP. IgG subclass profiles in infected HIV type 1 controllers and chronic progressors and in uninfected recipients of Env vaccines. AIDS Res Hum Retroviruses. 2010;26:445-58.

57. Ackerman ME, Crispin M, Yu X, Baruah K, Boesch AW, Harvey DJ, Dugast AS, Heizen EL, Ercan A, Choi I, et al. Natural variation in Fc glycosylation of HIV-specific antibodies impacts antiviral activity. J Clin Invest. 2013;123:2183-92.

58. Tomaras GD, Ferrari G, Shen X, Alam SM, Liao HX, Pollara J, Bonsignori M, Moody MA, Fong $Y$, Chen $X$, et al. Vaccine-induced plasma IgA specific for the $\mathrm{C} 1$ region of the HIV-1 envelope blocks binding and effector function of lgG. Proc Natl Acad Sci USA. 2013;1 10:9019-24.

59. Watkins JD, Sholukh AM, Mukhtar MM, Siddappa NB, Lakhashe SK, Kim M, Reinherz EL, Gupta S, Forthal DN, Sattentau QJ, et al. Anti-HIV IgA isotypes: differential virion capture and inhibition of transcytosis are linked to prevention of mucosal R5 SHIV transmission. AIDS. 2013;27:F13-20.

60. Baum LL, Cassutt KJ, Knigge K, Khattri R, Margolick J, Rinaldo C, Kleeberger CA, Nishanian P, Henrard DR, Phair J. HIV-1 gp120-specific antibody-dependent cell-mediated cytotoxicity correlates with rate of disease progression. J Immunol. 1996;157:2168-73.

61. Chung A, Rollman E, Johansson S, Kent SJ, Stratov I. The utility of ADCC responses in HIV infection. Curr HIV Res. 2008;6:515-9.

62. Ackerman ME, Moldt B, Wyatt RT, Dugast AS, McAndrew E, Tsoukas S, Jost S, Berger CT, Sciaranghella G, Liu Q, et al. A robust, high-throughput 
assay to determine the phagocytic activity of clinical antibody samples. J Immunol Methods. 2011;366:8-19.

63. Tay MZ, Liu P, Williams LD, McRaven MD, Sawant S, Gurley TC, Xu TT, Dennison SM, Liao HX, Chenine AL, et al. Antibody-mediated internalization of infectious HIV-1 virions differs among antibody isotypes and subclasses. PLoS Pathog. 2016;12:e1005817.

64. Stratov I, Chung A, Kent SJ. Robust NK cell-mediated human immunodeficiency virus (HIV)-specific antibody-dependent responses in HIV-infected subjects. JVirol. 2008;82:5450-9.

65. Gunn BM, Schneider JR, Shansab M, Bastian AR, Fahrbach KM, Smith $A D$, Mahan AE, Karim MM, Licht AF, Zvonar l, et al. Enhanced binding of antibodies generated during chronic HIV infection to mucus component MUC16. Mucosal Immunol. 2016;9:1549-58.

66. Ahmad A, Menezes J. Antibody-dependent cellular cytotoxicity in HIV infections. Faseb J. 1996;10:258-66.

67. Tamura K, Shimizu C, Hojo T, Akashi-Tanaka S, Kinoshita T, Yonemori K, Kouno T, Katsumata N, Ando M, Aogi K, et al. FcgammaR2A and 3A polymorphisms predict clinical outcome of trastuzumab in both neoadjuvant and metastatic settings in patients with HER2-positive breast cancer. Ann Oncol. 2011;22:1302-7.

68. Forthal DN, Landucci G, Bream J, Jacobson LP, Phan TB, Montoya B. FcgammaRlla genotype predicts progression of HIV infection. J Immunol. 2007;179:7916-23.

69. Sanders LA, Feldman RG, Voorhorst-Ogink MM, de Haas M, Rijkers GT, Capel PJ, Zegers BJ, van de Winkel JG. Human immunoglobulin G (lgG) Fc receptor IIA (CD32) polymorphism and lgG2-mediated bacterial phagocytosis by neutrophils. Infect Immun. 1995;63:73-81.

70. Wang W, Erbe AK, Hank JA, Morris ZS, Sondel PM. NK cell-mediated antibody-dependent cellular cytotoxicity in cancer immunotherapy. Front Immunol. 2015;6:368.

71. Cartron G, Dacheux L, Salles G, Solal-Celigny P, Bardos P, Colombat P, Watier $\mathrm{H}$. Therapeutic activity of humanized anti-CD20 monoclonal antibody and polymorphism in IgG Fc receptor FcgammaRllla gene. Blood. 2002;99:754-8.

72. Poonia B, Kijak GH, Pauza CD. High affinity allele for the gene of FCGR3A is risk factor for HIV infection and progression. PLoS ONE. 2010;5:e15562.

73. Forthal DN, Gabriel EE, Wang A, Landucci G, Phan TB. Association of Fcgamma receptor Illa genotype with the rate of HIV infection after gp120 vaccination. Blood. 2012;120:2836-42.

74. Cheeseman HM, Carias AM, Evans AB, Olejniczak NJ, Ziprin P, King DF, Hope TJ, Shattock RJ. Expression profile of human fc receptors in mucosal tissue: implications for antibody-dependent cellular effector functions targeting HIV-1 transmission. PLOS ONE. 2016;11:e0154656.

75. Birmingham A, Selfors LM, Forster T, Wrobel D, Kennedy CJ, Shanks E, Santoyo-Lopez J, Dunican DJ, Long A, Kelleher D, et al. Statistical methods for analysis of high-throughput RNA interference screens. Nat Methods. 2009;6:569-75.

76. Alpert MD, Heyer LN, Williams DE, Harvey JD, Greenough T, Allhorn M, Evans DT. A novel assay for antibody-dependent cell-mediated cytotoxicity against HIV-1- or SIV-infected cells reveals incomplete overlap with antibodies measured by neutralization and binding assays. J Virol. 2012;86:12039-52.

77. Qin Z. The use of THP-1 cells as a model for mimicking the function and regulation of monocytes and macrophages in the vasculature. Atherosclerosis. 2012;221:2-11.

78. Raudys S, Jain A. Small sample size effects in statistical pattern recognition: recommendations for practitioners. IEEE Trans Pattern Anal Mach Intell. 1991;13:252-64.

79. Tarca AL, Carey VJ, Chen XW, Romero R, Draghici S. Machine learning and its applications to biology. PLoS Comput Biol. 2007;3:e116.

80. Nakaya HI, Li S, Pulendran B. Systems vaccinology: learning to compute the behavior of vaccine induced immunity. Wiley Interdiscip Rev Syst Biol Med. 2012;4:193-205.

81. Arnold KB, Chung AW. Prospects from systems serology research. Immunology. 2017. https://doi.org/10.1111/imm.12861

82. Choi I, Chung AW, Suscovich TJ, Rerks-Ngarm S, Pitisuttithum P, Nitayaphan S, Kaewkungwal J, O'Connell RJ, Francis D, Robb ML, et al. Machine learning methods enable predictive modeling of antibody feature:function relationships in RV144 vaccinees. PLoS Comput Biol. 2015;11:e1004185.
83. Lu LL, Chung AW, Rosebrock TR, Ghebremichael M, Yu WH, Grace PS, Schoen MK, Tafesse F, Martin C, Leung V, et al. A functional role for antibodies in tuberculosis. Cell. 2016;167(433-443):e414.

84. Chung AW, Kumar MP, Arnold KB, Yu WH, Schoen MK, Dunphy LJ, Suscovich TJ, Frahm N, Linde C, Mahan AE, et al. Dissecting polyclonal vaccine-induced humoral immunity against HIV using systems serology. Cell. 2015;163:988-98.

85. Archary D, Seaton KE, Passmore JS, Werner L, Deal A, Dunphy LJ, Arnold $\mathrm{KB}$, Yates NL, Lauffenburger DA, Bergin P, et al. Distinct genital tract HIV-specific antibody profiles associated with tenofovir gel. Mucosal Immunol. 2016;9:821-33.

86. Barouch DH, Alter G, Broge T, Linde C, Ackerman ME, Brown EP, Borducchi EN, Smith KM, Nkolola JP, Liu J, et al. Protective efficacy of adenovirus-protein vaccines against SIV challenges in rhesus monkeys. Science. 2015;349:320-4.

87. Brown EP, Dowell KG, Boesch AW, Normandin E, Mahan AE, Chu T, Barouch DH, Bailey-Kellogg C, Alter G, Ackerman ME. Multiplexed FC array for evaluation of antigen-specific antibody effector profiles. J Immunol Methods. 2017;443:33-44.

88. Johnstone IM, Titterington DM. Statistical challenges of high-dimensional data. Philos Trans A Math Phys Eng Sci. 2009;367:4237-53.

89. Saeys $Y$, Inza I, Larranaga P. A review of feature selection techniques in bioinformatics. Bioinformatics. 2007;23:2507-17.

90. Querec TD, Akondy RS, Lee EK, Cao W, Nakaya HI, Teuwen D, Pirani A, Gernert K, Deng J, Marzolf B, et al. Systems biology approach predicts immunogenicity of the yellow fever vaccine in humans. Nat Immunol. 2009;10:116-25.

91. Nakaya HI, Wrammert J, Lee EK, Racioppi L, Marie-Kunze S, Haining WN, Means AR, Kasturi SP, Khan N, Li GM, et al. Systems biology of vaccination for seasonal influenza in humans. Nat Immunol. 2011;12:786-95.

92. Vahey MT, Wang Z, Kester KE, Cummings J, Heppner DG Jr, Nau ME, Ofori-Anyinam O, Cohen J, Coche T, Ballou WR, Ockenhouse CF. Expression of genes associated with immunoproteasome processing of major histocompatibility complex peptides is indicative of protection with adjuvanted RTS, S malaria vaccine. J Infect Dis. 2010;201:580-9.

93. Kazmin D, Nakaya HI, Lee EK, Johnson MJ, van der Most R, van den Berg RA, Ballou WR, Jongert E, Wille-Reece U, Ockenhouse C, et al. Systems analysis of protective immune responses to RTS, S malaria vaccination in humans. Proc Natl Acad Sci U S A. 2017;114:2425-30.

94. Churchyard GJ, Morgan C, Adams E, Hural J, Graham BS, Moodie Z, Grove D, Gray G, Bekker LG, McElrath MJ, et al. A phase IIA randomized clinical trial of a multiclade HIV-1 DNA prime followed by a multiclade rAd5 HIV-1 vaccine boost in healthy adults (HVTN204). PLoS ONE. 2011;6:e21225

95. Tibshirani R. The lasso method for variable selection in the Cox model. Stat Med. 1997;16:385-95.

96. Arnold KB, Burgener A, Birse K, Romas L, Dunphy LJ, Shahabi K, Abou M, Westmacott GR, McCorrister S, Kwatampora J, et al. Increased levels of inflammatory cytokines in the female reproductive tract are associated with altered expression of proteases, mucosal barrier proteins, and an influx of HIV-susceptible target cells. Mucosal Immunol. 2015;9:194.

97. Barabasi AL, Oltvai ZN. Network biology: understanding the cell's functional organization. Nat Rev Genet. 2004;5:101-13.

98. Yook SH, Oltvai ZN, Barabasi AL. Functional and topological characterization of protein interaction networks. Proteomics. 2004;4:928-42.

99. Bradley T, Pollara J, Santra S, Vandergrift N, Pittala S, Bailey-Kellogg C, Shen X, Parks R, Goodman D, Eaton A, et al. Pentavalent HIV-1 vaccine protects against simian-human immunodeficiency virus challenge. Nat Commun. 2017:8:15711.

100. Vaccari M, Gordon SN, Fourati S, Schifanella L, Liyanage NPM, Cameron $M$, Keele BF, Shen $X Y$, Tomaras GD, Billings E, et al. Adjuvant-dependent innate and adaptive immune signatures of risk of SIVmac251 acquisition. Nat Med. 2016;22:762-70.

101. Hu SL. Non-human primate models for AIDS vaccine research. Curr Drug Targets Infect Disord. 2005;5:193-201.

102. Chan YN, Boesch AW, Osei-Owusu NY, Emileh A, Crowley AR, Cocklin SL, Finstad SL, Linde CH, Howell RA, Zentner I, et al. IgG binding characteristics of rhesus macaque FcgammaR. J Immunol. 2016;197:2936-47.

103. Liao HX, Lynch R, Zhou T, Gao F, Alam SM, Boyd SD, Fire AZ, Roskin KM, Schramm CA, Zhang $Z$, et al. Co-evolution of a broadly neutralizing HIV-1 antibody and founder virus. Nature. 2013;496:469-76. 
104. Brown EP, Licht AF, Dugast AS, Choi I, Bailey-Kellogg C, Alter G, Ackerman ME. High-throughput, multiplexed lgG subclassing of antigen-specific antibodies from clinical samples. J Immunol Methods. 2012;386:117-23

105. Klasse PJ. How to assess the binding strength of antibodies elicited by vaccination against HIV and other viruses. Expert Rev Vaccines. 2016;15:295-311.

106. Mahan A, Tedesco J, Dionne K, Chung A, Cox J, Koff W, Barouch D, Michael N, Kim J, Suscovich T, Alter G: Antibody Glycosylation Can Be Transiently Altered After Vaccination Against HIV. AIDS Vaccine Barc 2013, P03.18.

107. Luo Y, Lu Z, Raso SW, Entrican C, Tangarone B. Dimers and multimers of monoclonal lgG1 exhibit higher in vitro binding affinities to Fcgamma receptors. MAbs. 2009;1:491-504.

108. Lan J, Yang K, Byrd D, Hu N, Amet T, Shepherd N, Desai M, Gao J, Gupta S, Sun Y, Yu Q. Provirus activation plus CD59 blockage triggers antibodydependent complement-mediated lysis of latently HIV-1-infected cells. J Immunol. 2014;193:3577-89.

109. Sips M, Krykbaeva M, Diefenbach TJ, Ghebremichael M, Bowman BA, Dugast AS, Boesch AW, Streeck H, Kwon DS, Ackerman ME, et al. FC receptor-mediated phagocytosis in tissues as a potent mechanism for preventive and therapeutic HIV vaccine strategies. Mucosal Immunol. 2016;9:1584-95.

110. Forthal DN, Landucci G, Ding H, Kappes JC, Wang A, Thung I, Phan T. IgG2 inhibits HIV-1 internalization by monocytes, and lgG subclass binding is affected by gp120 glycosylation. AIDS. 2011;25:2099-104

111. Ana-Sosa-Batiz F, Johnston AP, Liu H, Center RJ, Rerks-Ngarm S, Pitisuttithum P, Nitayaphan S, Kaewkungwal J, Kim JH, Michael NL, et al. HIV-specific antibody-dependent phagocytosis matures during HIV infection. Immunol Cell Biol. 2014;92:679-87.
112. Ahmad A, Morisset R, Thomas R, Menezes J. Evidence for a defect of antibody-dependent cellular cytotoxic (ADCC) effector function and anti-HIV gp120/41-specific ADCC-mediating antibody titres in HIVinfected individuals. J Acquir Immune Defic Syndr. 1994;7:428-37.

113. Gomez-Roman VR, Florese RH, Patterson LJ, Peng B, Venzon D, Aldrich K, Robert-Guroff M. A simplified method for the rapid fluorometric assessment of antibody-dependent cell-mediated cytotoxicity. J Immunol Methods. 2006;308:53-67.

114. Pollara J, Hart L, Brewer F, Pickeral J, Packard BZ, Hoxie JA, Komoriya A Ochsenbauer C, Kappes JC, Roederer M, et al. High-throughput quantitative analysis of HIV-1 and SIV-specific ADCC-mediating antibody responses. Cytometry A. 2011;79:603-12.

115. Alpert MD, Heyer LN, Williams DE, Harvey JD, Greenough T, Allhorn M, Evans DT. A novel assay for antibody-dependent cell-mediated cytotoxicity against HIV-1- or SIV-infected cells reveals incomplete overlap with antibodies measured by neutralization and binding assays. J Virol. 2012;86:12039-52.

116. Guan Y, Pazgier M, Sajadi MM, Kamin-Lewis R, Al-Darmarki S, Flinko R, Lovo E, Wu X, Robinson JE, Seaman MS, et al. Diverse specificity and effector function among human antibodies to HIV-1 envelope glycoprotein epitopes exposed by CD4 binding. Proc Natl Acad Sci U S A. 2013;110:E69-78.

117. Richard J, Veillette M, Brassard N, lyer SS, Roger M, Martin L, Pazgier M, Schon A, Freire E, Routy JP, et al. CD4 mimetics sensitize HIV-1-infected cells to ADCC. Proc Natl Acad Sci U S A. 2015;112:E2687-94.

118. Chung AW, Navis M, Isitman G, Wren L, Silvers J, Amin J, Kent SJ, Stratov I. Activation of NK cells by ADCC antibodies and HIV disease progression. J Acquir Immune Defic Syndr. 2011;58:127.

\section{Submit your next manuscript to BioMed Central and we will help you at every step:}

- We accept pre-submission inquiries

- Our selector tool helps you to find the most relevant journal

- We provide round the clock customer support

- Convenient online submission

- Thorough peer review

- Inclusion in PubMed and all major indexing services

- Maximum visibility for your research

Submit your manuscript at www.biomedcentral.com/submit
() Biomed Central 